\title{
Emerging base for telE-learning in India
}

\author{
Rakesh M. Bhatt and Krishnamurthy Subramanian \\ Department of Computer Science, HNB Garhwal University, Srinagar, India \\ Deputy Director General, CAG, Government of India, New Delhi
}

\begin{abstract}
India's National Population Policy says that India has 16 percent of the world population in only 2.4 percent of the global land area. Due to this current population problem, India's power to generate non-literate individuals is much greater than other countries. India cannot afford the huge expenditure to procure the facilities provided in a conventional style to support the education system. Furthermore, the ongoing development in technological infrastructure has strengthened the base for telE-learning and teaching. Thus, physical distances are virtually vanishing and information and communication technologies (ICT) are becoming increasingly a vital tool for educational purposes. In this context, emergence of technological scenarios relevant to education in India are discussed in the present paper.
\end{abstract}

Key words: technological infrastructure, telE-learning

\section{INTRODUCTION}

Swami Vivekananda said (in Lakshmi, 1994) institutions of higher education are meant for man-making and character-building and, unless such a mission is undertaken in all seriousness by higher educational institutions, the nation and the world will continue to be destroyed by violence and other evil. India has a large population and so has more non-literates than other countries. At the world level, according to the declaration of the 21st World Congress on Higher Education in October 1998 in Paris, the number of students has increased 6.5 times approximately from the year 1960 to 1995.

The original version of this chapter was revised: The copyright line was incorrect. This has been corrected. The Erratum to this chapter is available at DOI: 10.1007/978-0-387-35615-0_52 
India's National Population Policy (2000) says that India has 16 per cent of the world population in only 2.4 per cent of the global land area.

\section{EDUCATIONAL SCENARIO}

Failing to educate the population in controlling birth rate has been considered to be a main drawback of the education system. This is felt to be due to an absence of a proper feedback process across the different education departments. Teachers and students have to travel often from far-flung remote areas to their schools and it becomes difficult to synchronise the learning process. Therefore, some strategy needs to be developed by the school management to cover this type of situation.

It was reported (in Sharma, 2000) in the survey during the year 1995 by the National Council for Education and Research (NCERT) that 50 percent of students admitted to class-I could reach class-V. It is difficult to attain a high intake rate at the higher education level, where enrolment covers (Deshmukh, 1999) only 6 percent of the age group of 17 to 24 year olds. If we analyse government expenditures, it is found that the share for higher education (Sharma, 2000) from the total expenditure on education in the five-year plan during 1992-97 was 8 percent; which was the lowest share. Presently, government spends 3.8 percent of the GNP on all levels of education. Moreover, the disadvantaged and remotely placed groups are badly affected. Due to this, the call given from government towards 'education for all by 2000' was not a success. However, in its budget, government has also reduced the price of IT items and the ninth year plan (1997-2002) also envisaged the need for open learning both at secondary and tertiary level. Recently the Indian government has declared that it will provide free and compulsory education to this group of children. Under these developments, it is envisaged that education for all the children of the age group 6-14 years by the year 2003 will be achieved and it is hoped to raise the total literacy rate above $75 \%$ from $61 \%$.

\section{ICT FOR THE EDUCATION SYSTEM}

A plan is being developed by the government to make India a superpower in the field of information technology by 2008 . Under this plan, a task force has already been formed and IT policy has been designed to promote the software and hardware industry to compete in the global market. This IT task force has recommended that by 2008 there should be one personal computer for each group of 50 persons. Further, under the New Telecomm Policy 
(1999), it is envisaged that high speed and multimedia facilities will be provided by 2002 in cities which have a population around 0.2 million. With the emergence of IT as a powerful tool and its appropriate applications to help in delivering education, India has achieved a formidable job through the support of some institutions (Bhatt, 1998).

India is culturally a very rich country. ICT can help to revive the traditional knowledge region-wise and disseminate it for cultural integration. ICT would also support strongly our national integration, as area-specific problems can be better understood and controlled. In implementing digital education, the concept of sharing resources has led to a great deal of discussion. Along this path, a vision for an education framework has been envisaged (Subramanian, 2000) based on four pillars, which are 'Learning to Know', 'Learning to Do', 'Learning to Be', and 'Learning to Live Together'. Thus to meet these learning demands, a suitable infrastructure is required.

\section{INFRASTRUCTURAL DEVELOPMENTS}

India presently has 80.3 per cent of its area covered by terrestrial wire with 72.9 per cent at TV density, covering 87.6 per cent of the population. During the year 1999, the total number of viewers was 362 million with an estimated count of TV households of around 75 million. This has enabled a good educational awareness building process across society. In addition, cable TV and satellite TV viewers have also been estimated at around 150 million. A study conducted in some of the rural areas to examine the impact of the development of specifically oriented television programmes has shown strong results when social issues like legal age of marriage, dowry system, rural employment and equality of religions are considered. India has registered among 11 other nations to provide e-business. With this step, it is felt that ICT to support educational activities could be administered effectively.

\section{CONCLUSION}

In terms of using IT, in the future, syllabuses could be standardised and uniformly implemented irrespective of elite groups and disadvantaged groups. New products and internet technologies should be integrated with the existing infrastructure and legacy systems should be put in place to enable educational institutions to lever their technology investment and evolve ICT-based education more smoothly. 


\section{REFERENCES}

Lakshmi, S. (1994) Revamping higher education. In M.V. Mathur, R.K. Arora and M. Sogan (eds.). Indian University System-Revitalization and Reform. New Delhi: Wiley Eastern Ltd.

Anandi, Krishna Swarup, Amar Ujala (a daily Hindi newspaper). 16th November 1999

Sharma, S. (2000). Influence of gender and region (rural/urban) on achievement of primary school children. A DPEP Newsletter, published by the Ministry of Human Resource and Development, Government of India, Vol. IV, Nos. 2-4, 30

Deshmukh, K.G. (1999) University and higher education in the 21st century. Journal of Higher Education, 36, 28, 4

Sharma, V. (2000) Reduces funding and a big fee hike. University Today, xx, 17

Bhatt, R.M. (1998) Progress of virtual-teaching process in India. In G. Davis (ed.) Proceedings of World Computer Congress, Vienna and Budapest.

Subramanian, K. (2000) Education for all in the new millenium-vision for India 2020. In D. Benzie and D. Passey (eds.) Proceedings of the 16th World Computer Congress, Beijing, China.

\section{BIOGRAPHY}

R. M. Bhatt, Ph.D. is a senior life member of CSI and is associated with WG 3.6. He has written over 30 papers in proceedings and journals of national and international repute.

K. Subramanian, Ph.D. is deputy director general at NIC, New Delhi and also visiting professor at IIT Delhi. He is chairman of the hardware division (hardware) of the Computer Society of India and a senior member of IEEE (USA).

\section{ACKNOWLEDGEMENT}

Dr. R. M. Bhatt acknowledges the encouragement received from Prof. A. N. Purohit, Vice Chancellor, HNBG University, and the late Mrs. Sushila Devi. 